\title{
Irradiation Treatment of Animal Foods
}

\author{
Marsida Klemo \\ PhD, Engineering Sciences Department, "Alexandër Moisiu" University, Durres, Albania \\ Email:marsi_82h@yahoo.com
}

\author{
Azem Hysa \\ MSc, Engineering Sciences Department, "Alexandër Moisiu" University, Durres, Albania \\ Email: azemhysa@gmail.com
}

\section{Stela Sefa}

MSc. Ing, Engineering Sciences Department, "Alexandër Moisiu" University, Durres, Albania Email: stelasefa@gmail.com

\section{Doi:10.5901/ajis.2015.v4n3s1p256}

\begin{abstract}
The presence of pathogenic microbes in food is a serious global problem. Irradiation, as an effective method, destroy pathogens reducing threat that come by uncontrolled food. In this paper we have treated irradiation of animal foods and its effect, to decrease total microbial load on them. Foods were irradiated with a gamma irradiator GU-3 (Cs-137 source) with the rotation technique. Uniformity dose rate used was $106 \%$ and average dose rate $4.68 \mathrm{~Gy} / \mathrm{min}$. According to standards, doses used to irradiate food varied from 0 to $5 \mathrm{kGy}$. From experimental results it was observed that with increasing absorbed dose, total microbial load was reduced with some orders. Variation of $\log N$ / NO ( $N$ - total microbial load of irradiated food and NO of non-irradiated food) with dose, was approximated linearly. Based on this variation was defined D10, as the dose that cause "death" of about $90 \%$ of microbes in food ( $\log \mathrm{N} / \mathrm{NO}=-1)$. $D$ values found experimentally had a good correspondence with them defined theoretically (D10 = $\mid 1$ / slope $\mid)$.
\end{abstract}

Keywords: gamma irradiation, animal food, dose, biological effect

\section{Introduction}

Public concern about food safety has increased. Despite efforts to control food spoilage and improve safety, food microbiological hazards still exist. Meat and poultry account for a large number of foodborne illnesses and deaths; however, the amount of illness related to pathogens in produce now is greater (Eustice \& Bruhn).

Irradiation technology is one of the techniques that has aided in the reduction of harmful pathogens in a number of foods, thereby preventing illness and death caused by foodborne illness.

This technology, in relation to the food supply, is a process in which food is exposed to radiant energy in quantities great enough to cause bacteria and other harmful microbes to become inactive

(http://www.recipetips.com/kitchen-tips/t--1218/irradiation-technology.asp).

Hospitals have used irradiation for many years to sterilize food for cancer patients and others with weakened immune systems. Some perishable food taken into space by astronauts is irradiated because the food must be guaranteed free of disease-causing organisms.

(http://dwb.unl.edu/teacher/nsf/c10/c10links/www.fsis.usda.gov/oa/pubs/qa_irrad.htm)

According to the International Atomic Energy Agency (IAEA), more than 50 countries have approved the use of irradiation for about 50 different types of food, and 33 are using the technology commercially (http://www.cfs.gov.hk/ english/programme/programme_rafs/files/RA_37_Safety_of_Irradiated_Food_final.pdf ).

Although public knowledge about irradiation continues to be limited, interest in purchasing safety-enhanced irradiated food is increasing, especially after people receive information about potential benefits and risks. 


\section{Materials and Methods}

In this study were used different animal food products like: fresh milk, cottage cheese, pork meat, sausages, minced and chicken meat. The weight of every product was $30 \mathrm{gram}$. They were packed in sterile plastic bags and were conserved in freeze, at about $3-4^{\circ} \mathrm{C}$.

Products were irradiated using gamma irradiator GU-3 installed in the Institute of Applied Nuclear Physics (with Cs137 source and energy $0.66 \mathrm{MeV}$ ) with the below technique and geometry (fig 1).

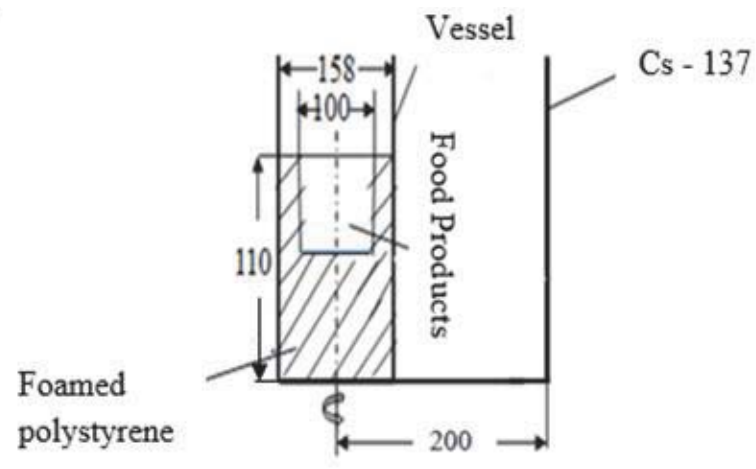

Figure 1. Irradiation technique and geometry of food products (Dimensions are given in $\mathrm{mm}$ )

To provide a very good dose uniformity (during irradiation period) it was used the rotation technique of vessel with the biological product inside it.

Doses used to irradiate products were 0-5 kGy. The average dose rate was $\mathrm{P}=4.68 \mathrm{~Gy} / \mathrm{min}$ and uniformity dose rate $D_{\max } / D_{\min }=106 \%$ (Klemo \& Dodbiba, 2012).

After irradiation, products were sent in the Institute of Food Safety and Veterinary (the only national reference center in Albania for microbial analysis).

\section{Effects of Irradiation in Food}

When microbes present in food are irradiated, their DNA is destroyed causing defects in their genetic code. If this defect it's not repaired, microbe will "die" or will be unable to reproduce. Effectiveness of the process depends on microbe sensitivity toward irradiation, the rate of DNA damage repair and especially by the DNA size of microbe (Alam \& Abrahem, 2010), (Ahmed, 2005).

High sensitivity of DNA by irradiation is because that DNA is greater than other molecular structures inside cell.

Damage of DNA by irradiation is caused in two ways:

\subsection{Direct way}

Ionization radiation produce too many damages in the DNA molecule that include the change of its base like: rupture of single and double bonds. The main action of this effect in the biological system is the rupture of DNA double bond like in figure 2. 


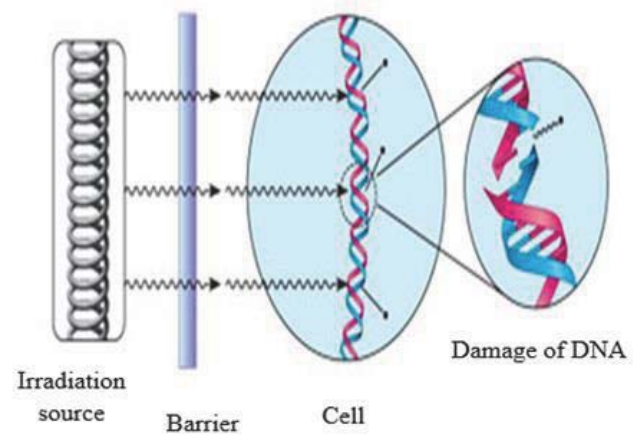

Figure 2. Ionization irradiation action in the DNA of microorganisms

\subsection{Indirect way}

Indirect damage of DNA is caused by free radicals that are formed as a result of ionization or excitation of water components in the cellular structure. Ionization creates the division of water molecules in hydrogen ion $(\mathrm{H}+)$, hydroxyl $\left(\mathrm{OH}^{-}\right)$and $\left(\mathrm{O}^{2-}\right)$ radicals. These radicals destroy and disable bacterial components like DNA, cell membranes etc (Ahmed 2005), (Alam \& Abrahem, 2010), (IAEA Buletin, 2007).

\section{Results and Discussion}

Results obtained from analysis done in the Institute of Food Safety and Veterinary are given in table 1, where: Dose 0 is the dose for non-irradiated product (control); $\mathrm{N}$ is the number of living microorganisms after irradiating with dose $\mathrm{D}$; $\mathrm{N}_{0}$ is the number of living microorganisms for control.

The number of living microorganisms it is measured in collg for all the animal products in table 1, except the milk product that is measured in $\mathrm{col} / \mathrm{mL}$.

Table 1. Microbial load results in animal food

\begin{tabular}{|c|c|c|c|c|}
\hline Animal food products & $D(k G y)$ & $\begin{array}{c}\mathrm{N}_{\mathrm{o}}(\mathrm{col} / \mathrm{g}) \\
\mathrm{Or}(\mathrm{col} / \mathrm{mL})\end{array}$ & $\begin{array}{c}\mathrm{N}(\mathrm{col} / \mathrm{g}) \\
\text { or }(\mathrm{col} / \mathrm{mL})\end{array}$ & $\log \left(N^{\prime} N_{0}\right)$ \\
\hline \multirow{3}{*}{ Fresh milk } & 0 & \multirow{3}{*}{$3.5 \times 10^{5}$} & $3.5 \times 10^{5}$ & 0.00 \\
\hline & 1 & & $4.2 \times 10^{3}$ & -1.93 \\
\hline & 2 & & $4.1 \times 10^{3}$ & -1.92 \\
\hline \multirow{3}{*}{ Cottage cheese } & 0 & \multirow{3}{*}{$5.7 \times 10^{5}$} & $5.7 \times 10^{5}$ & 0.00 \\
\hline & 1 & & $3.2 \times 10^{5}$ & -0.25 \\
\hline & 2 & & $7.1 \times 10^{4}$ & -0.90 \\
\hline \multirow{4}{*}{ Minced meat } & 0 & \multirow{4}{*}{$7.3 \times 10^{6}$} & $7.3 \times 10^{6}$ & 0.00 \\
\hline & 2 & & $1.8 \times 10^{4}$ & -2.61 \\
\hline & 2.7 & & $1.1 \times 10^{4}$ & -2.82 \\
\hline & 5 & & $<10$ & -5.86 \\
\hline \multirow{3}{*}{ Pork meat } & 0 & \multirow{3}{*}{$1.6 \times 10^{6}$} & $1.6 \times 10^{6}$ & 0.00 \\
\hline & 1.7 & & $1.3 \times 10^{4}$ & -2.09 \\
\hline & 3 & & $2.3 \times 10^{3}$ & -2.84 \\
\hline \multirow{4}{*}{ Sausages } & 0 & \multirow{4}{*}{$1.0 \times 10^{4}$} & $1.0 \times 10^{4}$ & 0.00 \\
\hline & 2 & & $<10$ & -2.04 \\
\hline & 2.7 & & $<10$ & -2.04 \\
\hline & 5 & & $<10$ & -2.04 \\
\hline \multirow{3}{*}{ Chicken meat } & 0 & \multirow{3}{*}{$6.4 \times 10^{4}$} & $6.4 \times 10^{4}$ & 0.00 \\
\hline & 1 & & $2.2 \times 10^{4}$ & -0.46 \\
\hline & 2 & & $1.2 \times 10^{3}$ & -0.73 \\
\hline
\end{tabular}


From the data table it's observed that in the case of milk, from the dose 1 to 2 kGy there isn't any change in the number of living microorganisms.

Similar case is observed also for sausages irradiated with doses 2 to $5 \mathrm{kGy}$.

With data table 1 (dose $D$ and $\log N / N_{0}$ ) are constructed linear regress curves for every product.

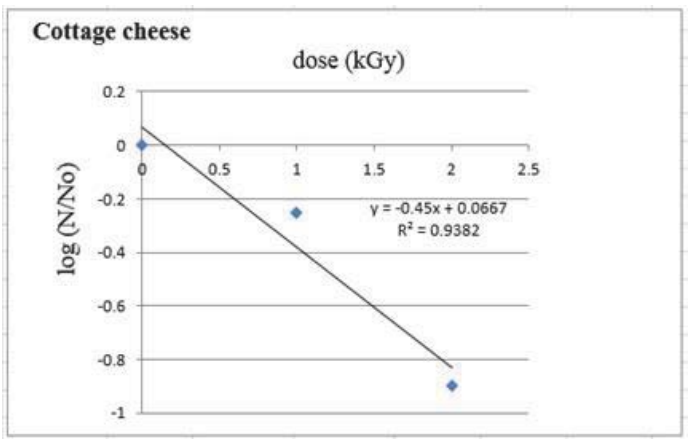

Figure 3. Cottage cheese product

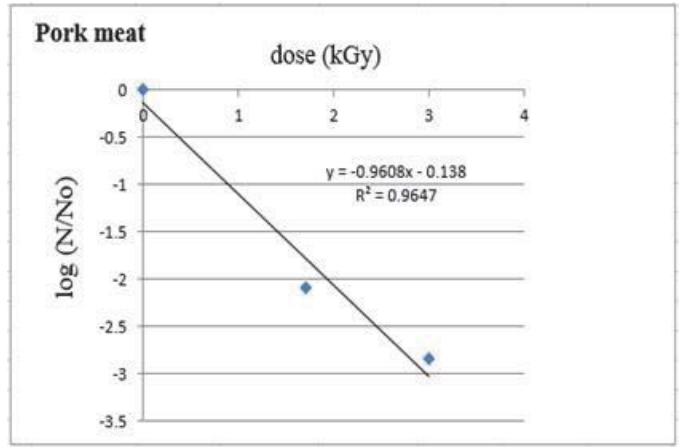

Figure 4. Pork meat product

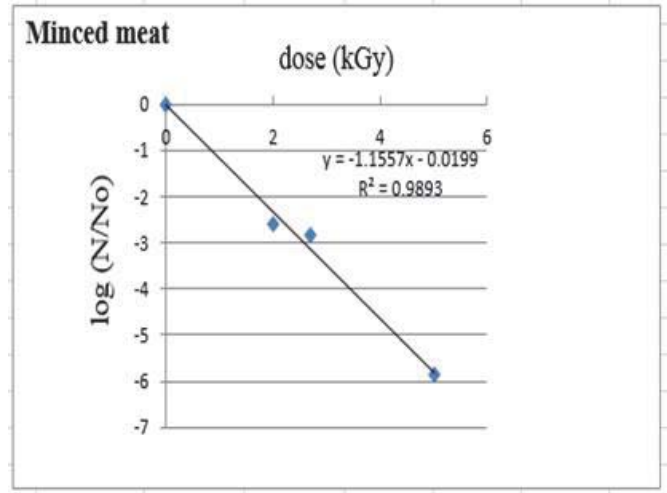

Figure 5. Minced meat product 


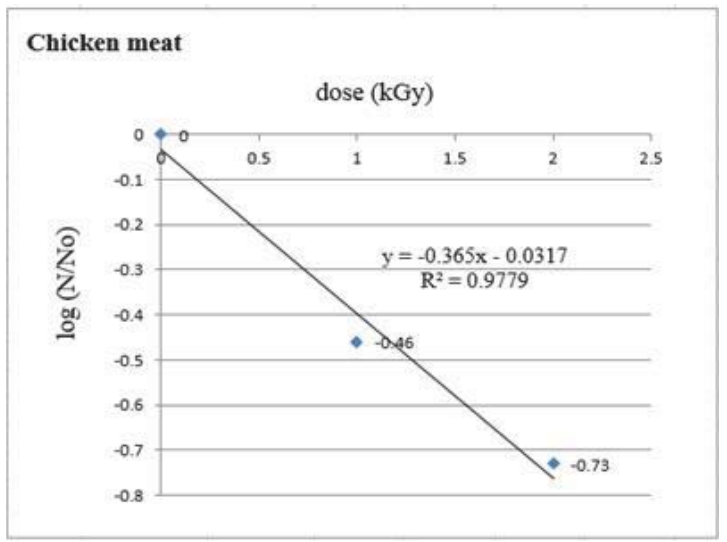

Figure 6. Chicken meat product

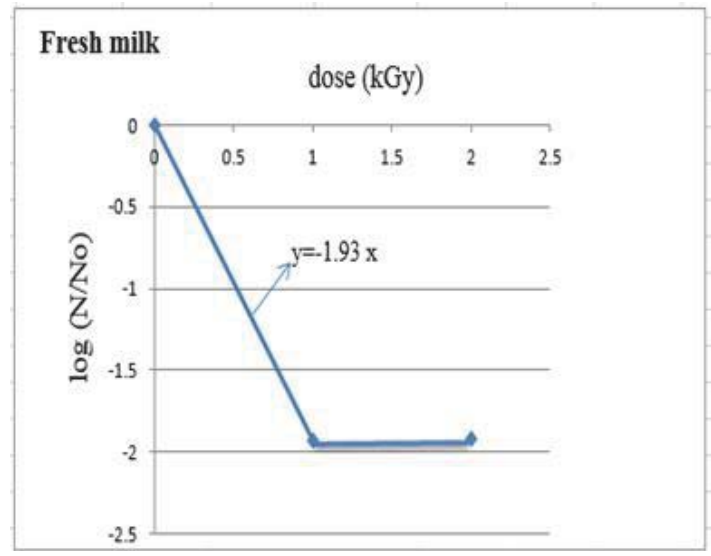

Figure 7. Fresh milk product

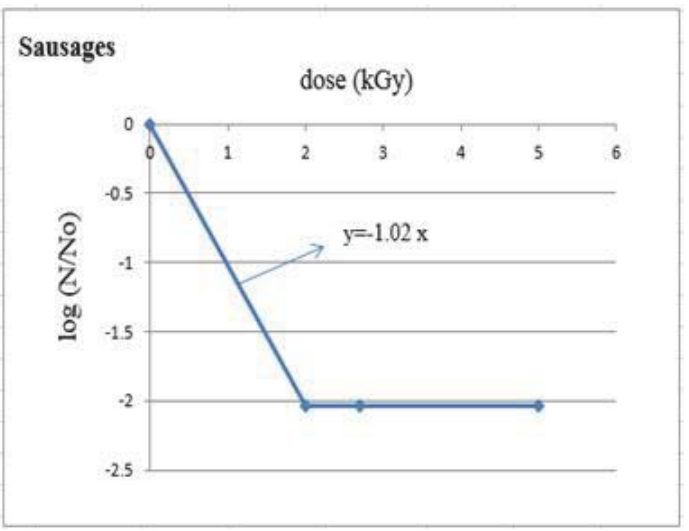

Figure 8. Sausages products 
From graphics above it is observed that, with increasing absorbed dose total microbial load is decreased. In many cases this decrease varies from $10^{4} \mathrm{col} / \mathrm{g}$ for control to $<10 \mathrm{col} / \mathrm{g}$ for irradiated product. Referring to (Lund et.al, 2000) in many cases for high doses it is seen "a tail" in graphics

(fig 7, 8).

Horizontal part in the graphic indicates that with increasing dose total microbial load does not change.

Their sensitivity toward irradiation can be defined by $D_{10}$ dose value. This is the dose that makes inactive $90 \%$ of microorganisms in the product (log N/No $=-1$ ) (Lund et.al, 2000), (Nketsia-Tabiri et.al, 2009).

Referring to (Nketsia-Tabiri et al, 2009), the equation that calculates $D_{10}$ is given by the formula:

$D_{10}=D /\left|\log N / N_{0}\right|$

According to formula (1), $D_{10}$ is calculated as reciprocal slope of linear curve:

$D_{10}=-1 /$ slope

For every product (fig $3 \div 8$ ) are determined experimental values of $D_{10}$ (taken by corresponding curves) and theoretical values referring the above expression (2). It is observed that there is a very good accordance between these values (table 2).

Table 2. Rate of $D_{10}$ (theoretical)/ $D_{10}$ (experimental) in $\%$

\begin{tabular}{|l|c|c|c|}
\hline Animal food products & $\mathbf{D}_{10}$ (theoretical) $\mathbf{k} \mathbf{G}$ & $\mathbf{D}_{10}$ (experimental) $\mathbf{k G}$ & Rate $(\%)$ \\
\hline Fresh milk & 0.518 & 0.518 & 100 \\
\hline Cottage cheese & 2.20 & 2.37 & 93 \\
\hline Minced meat & 0.86 & 0.85 & 101 \\
\hline Pork meat & 1.04 & 0.90 & 115 \\
\hline Sausages & 0.98 & 0.98 & 100 \\
\hline Chicken meat & 2.74 & 2.83 & 97 \\
\hline
\end{tabular}

\section{Conclusions and Recommendations}

- With increasing absorbed dose it is observed a decrease of total microbial load. In many cases this decrease varies from $10^{4} \mathrm{col} / \mathrm{g}$ for control to <10 col/g for irradiated product (about 10000 times).

- May occur that, for high doses appear a "tail". This one indicates that with increasing dose, total microbial load doesn't change.

- For every animal product food, experimental values $D_{10}$ taken by respective curves with them defined theoretically have a very good accordance.

- It is important to apply this method also for dangerous pathogens to human lives.

\section{References}

Eustice, R. F., \& Bruhn, Ch. M. Consumer acceptance and marketing of irradiated foods (Chapter 10), Minnesota Beef Council, Minneapolis, USA.

Klemo, M., \& Dodbiba, A. (2012). Determination of the dose rate and some applications in the GU-3 gamma irradiator. AJTNS, No. 32, Tirane, 25-35.

Alam, K., \& Abrahem, M. (2010). Review article. Effect of irradiation on quality of spices. International Food Research Journal, 17, 825836.

Ahmed, R. G. (2005). Damage pattern as function of various types of radiation. Medical Journal of Islamic World, Academy of Sciences, vol. 15, no. 4, Egypt, 135-147.

IAEA Buletin. (2007). Food irradiation for fresh produce. Application of isotopes and radiation in agriculture, vol 21, no. 2/3.

Lund, B. M., Baird- Parker T. C., \& Gould G. W. (2000). The microbiological safety and quality of food, Vol.1, USA, 69.

Nketsia-Tabiri, J., Adu-Gyamfi, A., \& Apea Bah, F. (2009). Irradiation of prepared meals for microbiological safety and shelf life extension, IAEA, Vienna, Austria, 57. http://www.recipetips.com/kitchen-tips/t--1218/irradiation-technology.asp

http://dwb.unl.edu/teacher/nsf/c10/c10links/www.fsis.usda.gov/oa/pubs/qa_irrad.htm

http://www.cfs.gov.hk/english/programme/programme_rafs/files/RA_37_Safety_of_Irradiated_Food_final.pdf 